\title{
Effect of the Seasonal Changes on Renal Function in Patients with Acute Ischemic Stroke
}

\section{Akut İskemik İnmeli Hastalarda Mevsim Değiş̧ikliklerinin Böbrek Fonksiyonu Üzerindeki Etkileri}

\author{
(D) Güleser Akpınar1, (D) Mustafa Boğan1, (D) Kaan Yusufoğlu², (D) Miray Korkmaz³, (D) Emine Gül Baldane4, \\ (D) Erdem Çevik5
}

${ }^{1}$ Düzce University Faculty of Medicine, Department of Emergency Medicine, Düzce, Turkey

2Şişli Hamidiye Etfal Training and Research Hospital, Clinic of Emergency Medicine, İstanbul, Turkey

${ }^{3}$ Şişli Hamidiye Etfal Training and Research Hospital, Clinic of Neurology, İstanbul, Turkey

${ }^{4}$ Konya Training and Research Hospital, Clinic of Neurology, İstanbul, Turkey

5İstanbul Sultan 2.Abdulhamid Han Training and Research Hospital, Clinic of Emergency Medicine, İstanbul, Turkey

\section{Abstract}

Objective: This study aimed to define seasonality trends of acute renal dysfunction in the patients with ischemic stroke.

Method: This study was conducted retrospectively. Data were obtained from digital records of Şişli Hamidiye Etfal Training and Research Emergency Medicine Clinical Statistic Office.

Results: One hundred ninety-nine patients with ischemic stroke were included in the study. Patients were divided into two groups according to their renal functions. Group 1 (patients with abnormal renal function) included 70 patients. In this group, the mean urea value was $67.3 \pm 26.9$ $\mathrm{mg} / \mathrm{dL}$, the mean creatinine value was $1.4 \pm 1.1 \mathrm{mg} / \mathrm{dL}$, the mean age was $77.0 \pm 6.5$ years, 34 patients were male (48.6\%). Group 2 (patients with normal renal function) included 129 patients. In this group, the mean urea value was $37.9 \pm 9.9 \mathrm{mg} / \mathrm{dL}$, the mean creatinine value was $0.9 \pm 0.2 \mathrm{mg} /$ $\mathrm{dL}$, the mean age was $76.6 \pm 7.3$ years, 74 patients were male $(57.4 \%)$. Season distribution, age and gender distribution, affected area of the brain, and platelet count did not show significant differences between the groups $(p>0.05)$

Conclusion: There is not a significant relationship between seasonal changes and renal dysfunction in the patients with ischemic stroke.

Keywords: Emergency medicine, ischemic stroke, renal function, season

\section{Öz}

Amaç: Bu çalışma iskemik inmeli hastalarda akut böbrek fonksiyon bozukluğunun mevsimsellik eğilimlerini tanımlamayı amaçlamıştır.

Yöntem: Bu çalışma geriye dönük olarak yapılmıştır. Veriler Şişli Hamidiye Etfal Eğitim ve Araştırma Acil Tıp Klinik İstatistik Ofisi dijital kayıtlarından elde edilmiştir.

Bulgular: Çalışmaya 199 iskemik inme hastası dahil edilmiştir. Hastalar böbrek fonksiyonlarına göre iki gruba ayrılmıştır. Grup 1'e (anormal böbrek fonksiyonu olan hastalar) 70 hasta dahil edilmiştir. Bu grupta, ortalama üre $67,3 \pm 26,9 \mathrm{mg} / \mathrm{dL}$, ortalama kreatinin $1,4 \pm 1,1 \mathrm{mg} / \mathrm{dL}$, ortalama yaş $77,0 \pm 6,5$ olup, hastaların 34'ü erkekti (\%48,6). Grup 2'ye (normal böbrek fonksiyonu olan hastalar) 129 hasta alınmıştır. Bu grupta, ortalama üre $37,9 \pm 9,9 \mathrm{mg} / \mathrm{dL}$, ortalama kreatinin $0,9 \pm 0,2 \mathrm{mg} / \mathrm{dL}$, ortalama yaş $76,6 \pm 7,3$ olup, 74 hasta erkekti $(\% 57,4)$. Mevsim dağılımı, yaş ve cinsiyet dağılımı, beynin etkilenen bölgesi ve platelet sayısı gruplar arasında anlamlı farklılık göstermemiştir ( $p>0,05)$.

Sonuç: İskemik inmeli hastalarda mevsimsel değişiklikler ile böbrek fonksiyon bozukluğu arasında anlamlı bir ilişki yoktur.

Anahtar kelimeler: Acil tıp, böbrek fonksiyonu, iskemik inme, mevsim

\section{Introduction}

Stroke cases are caused by ischemic reasons at the rate of $80-85 \%$ and by hemorrhagic reasons at the rate of $15-20 \%$ (1). Acute stroke is the third most common cause of death and cause of morbidity and mortality around the world and in Turkey $(2,3)$. Even though there are many studies about stroke, risk factors are still not fully understood and have some contradictory elements (4).

Address for Correspondence: Mustafa Boğan, Düzce University Faculty of Medicine, Department of Emergency Medicine, Düzce, Turkey E-mail: mustafabogan@hotmail.com ORCID: orcid.org/0000-0002-3238-1827 Received: 25.02.2020 Accepted: 23.04.2020

Cite this article as: Akpınar G, Boğan M, Yusufoğlu K, Korkmaz M, Baldane EG, Çevik E. Effect of the Seasonal Changes on Renal Function in Patients with Acute Ischemic Stroke. Bagcilar Med Bull 2020;5(2):28-31

${ }^{\circ}$ Copyright 2020 by the Health Sciences University Turkey, Bagcilar Training and Research Hospital Bagcilar Medical Bulletin published by Galenos Publishing House. 
Many factors such as seasonal changes affect ischemic stroke. Results of the studies on the seasonality of stroke occurrence are not clear. Some of the studies have reported that stroke peaks in winter, spring or autumn, but some of the studies have reported no significant relationship between seasonal changes and stroke (5). In this study, we aimed to define the seasonality trends of acute renal dysfunction in the patients with ischemic stroke.

\section{Materials and Methods}

This study was conducted retrospectively. Patients who were diagnosed with acute ischemic stroke between the dates 01.01.2013 and 31.12.2014 at Şişli Hamidiye Etfal Training and Research Training and Research Hospital were included in the study. During this period, 305.300 patients presented into Şişli Hamidiye Etfal Training and Research Hospital. Data were obtained from digital records of Şişli Hamidiye Etfal Training and Research Emergency Medicine Clinical Statistic Office.

Inclusion criteria: Patients who

- were diagnosed with acute ischemic stroke on radiological imaging and clinical diagnosis,

- were $\geq 65$ years old,

Exclusion criteria: Patients who

- were $<65$ years old,

- were diagnosed with hemorrhagic stroke,

- had known chronical renal functional disorders.

\section{Measurements}

-Descriptive statistics of patients (gender, age, presentation dates, comorbidity (hypertension, diabetes mellitus, coronary artery disease and chronic obstructive lung disease, etc), situation of renal function (urea, creatinine), platelet counts (PC), mean platelet volume (MPV), computerized cranial tomography and diffusion magnetic resonance records).

-Patients were divided into two groups, Group 1 (patients with abnormal renal function = creatinin level $>1.2 \mathrm{mg} /$ $\mathrm{dL}$ and urea level $>45 \mathrm{mg} / \mathrm{dL}$ ) and Group 2 (patients with normal renal function).

\section{Statistical Analysis}

In data's descriptive statistics, average, standard deviation, the highest and the lowest median, frequency and rate values were used. Range of the variables was measured by the Kolmogorov-Smirnov test. In the analysis of quantitative data, the Kruskal-Wallis test, Mann-Whitney $\mathrm{U}$ test and independent sample t-test were used. In the analysis of qualitative data, the chi-square test was used. For analyzing, SPSS 22.0 program was used.

\section{Results}

One hundred ninety-nine patients with ischemic stroke were included in the study. $54.3 \%(\mathrm{n}=108)$ of the patients were male and the mean age of the patients was calculated to be $76.74 \pm 7.02$ years. One hundred ninety-nine (59.8\%) patients had a comorbid disease. Forty nine of the patients had new high-levels of urea and creatinine. Considering the presentation days of the patients, it was seen that $29.1 \%$ $(n=58)$ of the presentations were for autumn (Table 1).

Patients were divided into two groups according to their renal functions.

Group 1 (patients with abnormal renal function) included 70 patients. In this group, the mean urea value was $67.3 \pm 26.9$, the mean creatinine value was $1.4 \pm 1.1$, the mean age was $77.0 \pm 6.5$ years, 34 patients were male (48.6\%).

Group 2 (of the patients with normal renal function) included 129 patients. In this group, the mean urea value was $37.9 \pm 9.9$, the mean creatinine value was $0.9 \pm 0.2$, the mean age was $76.6 \pm 7.3$ years, 74 patients were male (57.4\%).

Season distribution, age and gender distribution, affected area of the brain, and PC did not show significant differences between the groups ( $p>0.05$ ). (Table 1). 59.8\% of the patients had at least one comorbid chronical disease, $65.8 \%$ of the patients in Group 1 had a comorbid chronical disease and it was remarkably higher than in Group 2 $(\mathrm{p}<0.05)$. MPV, urea, creatinine, and urea/creatinine levels were remarkably higher in Group $1(\mathrm{p}<0.05)$.

In Group 1, there was no correlation between age and renal functions (urea, creatinine, ure/creatinine) ( $p>0.05$ ). Creatinine and urea/creatinine levels were higher in men in this group $(p<0.05)$. There were no significant differences between renal functions (urea, creatinine, ure/creatinine) and variables of the patients (chronic disease, affected area of brain, and presented season) ( $\mathrm{p}>0.05)$ (Table 2) .

\section{Discussion}

The previous studies reported inconsistent results about the relationship between seasonal difference and ischemic stroke. In a prospective study conducted by Toyoda et al. (6), they analyzed 2.965 acute ischemic stroke patients and they did not find any significant difference between observing 
Table 1. Descriptive statistics and comparison of the groups

\begin{tabular}{|c|c|c|c|c|}
\hline Parameter & Total & Group 1 & Group 2 & $\mathbf{p}$ \\
\hline n (\%) & $199(100 \%)$ & $70(35.2 \%)$ & $129(64.8 \%)$ & \multirow[t]{2}{*}{-} \\
\hline Gender & Male: 108 (54.3\%) & Male: 34 (48.6\%) & Male: 74 (57.4\%) & \\
\hline Age & $76.74 \pm 7.02$ & $77.0 \pm 6.5$ & $76.6 \pm 7.3$ & 0.656 \\
\hline Comorbidity & $119(59.8 \%)$ & $46(65.7 \%)$ & $70(54.3 \%)$ & $0.031^{*}$ \\
\hline \multirow[t]{3}{*}{ Season } & Summer: 56 (28.1\%) & Summer: 24 (34.3\%) & Summer: 32 (24.8\%) & \multirow{2}{*}{0.422} \\
\hline & Autumn: 58 (28.2\%) & Autumn: 19 (27.1\%) & Autumn: 39 (30.2\%) & \\
\hline & Left anterior: 85 (42.7\%) & Left anterior: 31 (44.3\%) & Left anterior: 54 (41.9\%) & \multirow{2}{*}{0.209} \\
\hline Affected area of brain & Left posterior: $10(5 \%)$ & Left posterior: 6 (8.55\%) & Left posterior: 4 (3\%) & \\
\hline Creatinine & $1.15 \pm 0.7$ & $1.4 \pm 1.1$ & $0.9 \pm 0.2$ & $0.000 *$ \\
\hline Urea/Creatinine & $53.55 \pm 30.6$ & $60.1 \pm 29.3$ & $47.0 \pm 31.8$ & $0.000^{*}$ \\
\hline PC & $242 \pm 69$ & $240 \pm 64$ & $244 \pm 73$ & 0.693 \\
\hline MPV & $10.2 \pm 1$ & $10.5 \pm 0.9$ & $9.9 \pm 1.1$ & $0.003^{*}$ \\
\hline
\end{tabular}

*: Significant level $p<0.05$, PC: Platelet counts, MPV: Mean platelet volume

Table 2. Variable parameters in the patients of group 1

\begin{tabular}{lllll} 
& & Urea & Creatinine & $\begin{array}{l}\text { Urea/ } \\
\text { Creatinine }\end{array}$ \\
\hline \multirow{4}{*}{ Gender } & Male & $66.3 \pm 28.7$ & $1.7 \pm 1.4$ & $52.2 \pm 28.9$ \\
& Female & $68.4 \pm 25.2$ & $1.1 \pm 0.3$ & $68.4 \pm 27.8$ \\
Chronic & Y & 0.304 & $0.028^{*}$ & $0.006^{*}$ \\
& No & $70.7 \pm 29.0$ & $1.4 \pm 1.2$ & $63.8 \pm 30.9$ \\
Disease & $\mathbf{p}$ & $59.3 \pm 19.6$ & $1.3 \pm 0.7$ & $51.5 \pm 23.7$ \\
Affected & Anterior & $66.3 \pm 25.5$ & $1.3 \pm 0.7$ & $62.3 \pm 30.6$ \\
Area of the & Posterior & $72.1 \pm 34.0$ & $2.0 \pm 2.2$ & $49.2 \pm 19.5$ \\
Brain & $\mathbf{p}$ & 0.839 & 0.268 & 0.230 \\
\hline
\end{tabular}

*: Significant level $p<0.05$

stroke and seasons. However, they found that severe neurological deficits and one year mortality were frequent in the winter (6). Anlar et al. (7) reported that ischemic stroke was observed more frequently in males in hot seasons. In a meta-analysis, ischemic stroke rate peaked in cold seasons and it decreased in hot seasons (8). Karagiannis et al. (9) reported that ischemic stroke incidence peaked in the spring and reduced in the summer. It was reported that the, renal function was an important factor on long-term mortality in the patients with acute ischemic stroke (10). The incidence of acute renal dysfunction was found to be $8-21 \%$ in the patients with ischemic stroke (11). Wang et al. (12) reported that high rate of acute renal dysfunction was observed in the patients with ischemic stroke. It seems that renal function is a remarkable factor on the mortality and the morbidity of ischemic stroke. When we have investigated the studies on seasonal variation of the acute renal dysfunction, we have found that there are many studies but it is not clear like seasonal ischemic stroke variation. Iwagami et al. (13) found that acute renal dysfunction was seen higher in the winter and lower in the summer. Lim et al. (14) reported that acute renal dysfunction increased in hot and warm seasons because of increasing ambient temperature. Phillips et al. (15) found that acute cases with renal dysfunction increased in the first three months of the year, and decreased in the last three months of the year.

Although evidences are not clear about acute renal dysfunction and ischemic stroke, in this study, we aimed to define seasonality trends of acute renal dysfunction in the patients with ischemic stroke. We found that there was no significant relationship between seasons and renal dysfunction in the patients with ischemic stroke. This may be because that the population was small and the study was conducted in a single center. The records about seasonal variation of stroke in the literature vary, which may be because of the difference of geographical situation. Also, total population of the studies could affect the results.

Additionally, ischemic stroke is a result of many etiological factors such atrial fibrillation, hypercoagulable state (oral 
contraceptives, antiphospholipid antibodies, protein S and $\mathrm{C}$ deficiencies, sickle cell anemia), atherosclerosis, vasculitis, polycythemia etc.

If studies analyze the subgroups according to etiological factors, differences may be observed among the parameters.

\section{Study Limitations}

The study was conducted retrospectively and in a single center. It included a small population. Also, the study included only patients with ischemic stroke. The population of the study could not project all people that were affected by the seasonal changes.

\section{Conclusion}

There is not a significant relationship between seasonal changes and renal dysfunction in the patients with ischemic stroke.

\section{Ethics}

Ethics Committee Approval: The study was approved by Ethics Committee of Şişli Hamidiye Etfal Training and Research Hospital, İstanbul, Turkey (decision no: 2204, date: $08 / 01 / 2019$ ).

Informed Consent: Not required.

Peer-review: Externally peer-reviewed.

\section{Authorship Contributions}

Concept: G.A., Design: G.A., Data Collection or Processing: G.A., M.K., Analysis or Interpretation: M.B., E.G.B., Literature Search: G.A., K.Y., Writing: G.A., M.B., E.Ç.

Conflict of Interest: No conflict of interest was declared by the authors.

Financial Disclosure: The authors declared that this study has received no financial support.

\section{References}

1. Sacco PL. Vascular diseases. In: Merrit, Rowland LP, editors. Merrit's neurology. 10th ed. Hagerstown: Williams\&Wilkins; 2000 p.177-185.

2. Lopez AD, Mathers CD, Ezzati M, Jamison DT, Murray CJ. Global and regional burden of disease and risk factors, 2001: systematic analysis of population health data. The Lancet 2006;367(9524):7471757.
3. Onat A, Keleş İ, Çetinkaya A. On yıllık TEKHARF çalışması verilerine göre Türk erișkinlerinde koroner kökenli ölüm ve olayların prevalansı yüksek. Türk Kardiyoloji Derneği Arşivi 2001;29(1):8-19.

4. Feigin VL, Wiebers DO, Nikitin YP, O'Fallon WM, Whisnant JP. Risk factors for ischemic stroke in a Russian Community: A populationbased case control study. Stroke 1998;29(1):34-39.

5. Skajaa N, Horváth Puhó E, Sundbøll J, Adelborg K, Rothman KJ, Sørensen HT. Forty-year seasonality trends in occurrence of myocardial infarction, ischemic stroke, and hemorrhagic stroke. Epidemiology 2018;29(6):777-783.

6. Toyoda K, Koga M, Yamagami H, Yokota C, Sato S, Inoue M, et al. Seasonal Variations in Neurological Severity and Outcomes of Ischemic Stroke -5-Year Single-Center Observational Study.Circulation Journal 2018;82(5):1443-1450.

7. Anlar O, Tombul T, Unal O, Kayan M. Seasonal and environmental temperature variation in the occurrence of ischemic strokes and intracerebral hemorrhages in a Turkish adult population. Int $\mathrm{J}$ Neurosci 2002;112(8):959-963.

8. Li Y, Zhou Z, Chen N, He L, Zhou M. Seasonal variation in the occurrence of ischemic stroke: A meta-analysis. Environ Geochem Health 2019;41(5):2113-2130.

9. Karagiannis A, Tziomalos $\mathrm{K}$, Mikhailidis DP, Semertzidis $\mathrm{P}$, Kountana E, Kakafika AI, et al. Seasonal variation in the occurrence of stroke in Northern Greece: a 10 year study in 8204 patients. Neurological research 2010;32(3):326-331.

10. Tsagalis G, Akrivos T, Alevizaki M, Manios E, Stamatellopoulos $\mathrm{K}$, Laggouranis A, et al. Renal dysfunction in acute stroke: an independent predictor of long-term all combined vascular events and overall mortality. Nephrology Dialysis Transplantation 2008;24(1):94-200.

11. Fiaccadori E, Delsante M, Fani F, Regolisti G. Acute kidney injury and stroke: unresolved issues. Internal and Emergency Medicine 2017;13(1):13-15.

12. Wang D, Guo Y, Zhang Y, Li Z, Li A, Luo Y. Epidemiology of acute kidney injury in patients with stroke: a retrospective analysis from the neurology ICU. Internal and emergency medicine 2018;13(1):17-25.

13. Iwagami M, Moriya H, Doi K, Yasunaga H, Isshiki R, Sato I, et al. Seasonality of acute kidney injury incidence and mortality among hospitalized patients. Nephrology Dialysis Transplantation 2018;33(8):1354-1362.

14. Lim YH, So R, Lee C, Hong YC, Park M, Kim L, et al. Ambient temperature and hospital admissions for acute kidney injury: A time-series analysis. Science of The Total Environment 2018;616(617):1134-1138.

15. Phillips D, Young O, Holmes J, Allen LA, Roberts G, Geen J, et al. Seasonal pattern of incidence and outcome of Acute Kidney Injury: A national study of Welsh AKI electronic alerts. International journal of clinical practice 2017;71(9):e13000. 